tions on shore were secured by Capt. Wille. The necessary observations for compass error having been obtained, the Vorringen returned to Bergen, where the scientific staff was assembled. There was, however, something still wanting before we could put to sea: The accumulators used last year had got brittle, and new ones had been ordered from Loncon in March, but they had not arrived in May, and in answer to a telegram Capt. Wille learnt that the order had been forgotten. The new accumulators kept us waiting in Bergen till June IT, when we sailed for Stavanger, and received them on the 13 th, and we put to sea at once.

Outside the coast we took a series of temperatures, which showed the minimum, not at bottom, but at a certain depth below the surface. The same phenomenon has lately been observed in all latitudes near the coast. $I$ attribute it to the action of the winter cold on the sea.

Our first working station was in lat. $66^{\circ} 8^{\prime} \cdot 5$, long. $3^{\circ} \mathrm{o}^{\prime}$ E., which was reached on the morning of June 26 . The depth here was 805 fathoms, the temperature at bottom, $29^{\circ} .7$. We now worked in even sections, running westnorth-west and east-south-east perpendicular to the coast. The third section from lat. $67^{\circ} 53^{\prime}$, long. $5^{\circ} 12^{\prime} \mathrm{E}$. to the island of Trocuew having been completed, we went northwards into the West Fiord, where a series of temperatures was taken with Negretti and Zambra's deep-sea thermometer. Last year we could not use this instrument at sea because the slightest upward movement of the ship caused the thermometer to turn over before it had had sufficient time to accommodate itself to the temperature of the sea. This year it was fitted with a new turning apparatus devised by Capt. Wille, which proved satisfactory. In the outer part of the West Fiord the temperature on the surface was $45^{\circ} .7$; it decreased to $38^{\circ} .8$ in sixty fathoms; and from that point it rose to $41^{\circ} \mathrm{O}$ in 140 fathoms, ten fathoms above the bottom. The Casella-Miller thermometer of course registered from this depth the minimum $38^{\circ} .8$. The phenomenon here noticed is universal all along our coasts in the summer months; I discovered it for the first time in the West Fiord two years ago. The explanation seems to be this: In winter the air is generally cooler than the sea-surface, especially at the coast ; the water is chilled from above, and the cooled layer's being denser, sink down, and so the winter cold descends in the water; the temperature down to a certain depth increases with the deptb. When spring and summer come, the air warms up the sea surface, and the surface layers getting warmer get lighter also, and have no tendency to sink. The temperature becomes highest at the suiface, and decreases to a certain depth, below which the action of tire winter cold still shows itself in a iernperature increasing with the depth.

After drdging and trawling in the inner part of the West Fjord, we went to Boelö, where the expedition stayed a couple of days. On the 26 th we arrived at Rösh, the outermost of the Loffoden Islands; there we siayed some days, strengthening the accumulators, cleaning the ship, taking magnetical and astronomical observations, and making excursions.

We left Rösh on the 28th at noon, and commenced our work on the sections further north, sounded, dredged, and trawled outside the Loffoden Islands till the 3oth, when we went into the Hadsel Fjord, and anchored at Sortland in Westeraalen. The next week was spent in working outside Westeraalen. There the greatest depth for this year was reached, I,7ro fathoms in lat. $70^{\circ}$, long. $6^{\circ}$ I $5^{\prime} \mathrm{E}$. The Casella-Miller thermometer registered at the bottom a temperature of $28^{\circ} .4$ when corrected for instrumental error and for pressure, the lowest temperature hitherto found by our expedition. A series of temperature observations showed that the temperature at all depths decreased with the depth, and that $32^{\circ}$ lay in about 580 fathoms. The next Sunday, July 8 , found us in Tromsö.
The expedition has this summer been favoured with remarkably fine and quiet weather, which has allowed us to carry out all our operations according to our proposed plan. The number of sounding stations is already IOI ; last year's total was only 93. Seventeen serial temperatures have been obtained, and the dredge and trawl have been out on the bank in the Umbellularia region (one specimen has been caught), and in the deep biloculina clay, at the depth of 1,700 fathoms, animal life was rather scarce. The boundary line between the water above and below $32^{\circ}$ at the bottom, lies between lat. $65^{\circ}$ and the Arctic circle as far west as $5^{\circ} 30^{\prime} \mathrm{E}$. A little north of the Arctic circle it has a curvature towards the coast, and farther north it lies only from five to ten geographical miles off the outer side of the islands of Loffoden and Westeraalen. On this northern part the edge of the bank is very steep, and the bottom falls very rapidly towards the deep part of the Arctic Ocean. Out at sea the isothermal surface of $32^{\circ}$ lies at very different depths in different latitudes. In the channel between Faroe and Shetland, it lies in 300 fathoms, between Iceland and Norway it sinks to 400 fathoms, and between Jem Mengen and Norway we have found it in 580 fathoms. To the westward it rises, as we found last year, east of Iceland. How it behaves further north, off Spitzbergen, we expect to find next year. Near the coast, $32^{\circ}$ always lies at a much higher level.

The Umbellutaria region has been found extending as far down as 880 fathoms of Westeraalen, where the specimen found came up with the weights on the dredge rope. In several places off the coast we have found, besides Norwegian rocks, specimens of chalk and flint. Of deep-sea animals, some new species have been found. On the bank off Langenes (lat. $69^{\circ}$ ) we caught plenty of the same kind of fish as are caught at the bank fisheries on the "Storeggen," off the coast of Romsdal.

The expedition is now lying at Tromsö, refitting and taking in stores for further work. We intend first to work only two more sections north of Tromsö, and then call here to make all ready for the voyage to Jem Mengen. From that island the course will be westward till we reach ice-cold water, then southwards to a point midway between Jem Mengen and Iceland, and thence to Bodö, whence the expedition will return to Bergen.

Among the novelties used in our work this year I must mention a piezometer, kindly sent me by Mr. Buchanan, chemist of the Challenger. This instrument has registered the depth very well. A new atmometer of my own construction has been constantly in use, giving good results. Two such instruments have, under favourable circumstances (they cannot be used in rough weather), given aimost identical results; the depth of sea-water evaporated in twenty-four hours is sometimes more than four millimetres. Meteorological observations have been made every hour when at sea. The chemist has got many samples of air from the sea-water, both at the surface and at the bottom. He has taken the specific gravity of the water and determined its amount of chlorine. $\mathrm{He}$ has also made several determinations of its amount of carbonic acid.

\section{MR. FROUDE'S NEW DYNAMOMETER}

$\mathbb{M}$. FROUDE, in solving the problem assigned to him by the Admiralty - of producing a dynamometer calculated to test the power delivered at the end of the screw.shaft by largesized marine engines-has enabled us to utilise a new principle of great value among the "applications of science."

In the friction-brake dynamometer, as is well known, the power delivered to a-revolving shaft is measured by the rate at which a definite weight is being virtually lifted, and the number of foot. pounds of work done per minute is the circumference of the drum at the effective radius at which the weight is lifted, multiplied by the weight and by the numker of revolutions per minute. Simple as the arrangement is when employed on a small scale, it 
involves serious difficulties when greatly magnified, owing to the great amount of heat; and it was chiefly in order to escape this difficulty that Mr. Froude sought some fresh modus operandi, and ultimately felt his way to the arrangement to which we desire to draw attention.

Under this arrangement, the engine, in utilising its power, will still be virtually winding up a weight; but the weight, instead of being constant, will vary with the speed of rotation, much in the same way as the resistance of the propeller itself does; and thus the work performed by the engine under trial will more closely resemble its natural work.

The reaction, instead of arising from the continuous friction of two solid surfaces, will consist of a multitude of reactions supplied by the impact of a series of fluid jets or streams, which are maintained in a condition of intensified speed by a sort of turbine revolving within a casing filled with water, both being mounted on the end of the screw-shaft in place of the screw, the tuxbine revolving while the casing is held stationary; the jets being alternately dashed forward from projections in the turbine against counter-projections in the interior of the casing, tending to impress forward rotation on it, and in turn dashed back from the projections in the casing against those in the turbine, tending to resist its rotation. The important point is, that the speed of the jets is intensified by the reactions to which they are thus alternately subjected; and thus in virtue of this circumstance a total resistance of very great magnitude is main. tained within a casing of comparatively very limited dimensions.

The nature of this arrangement will be gathered from the accompanying figures.

In Fig. I, A A represents the screw-end of the screw shaft; 1: 13 shows in section what has been termed "the turbine;" it is a disc or circular plate, with a central boss, keyed to the screwshaft: in place of the screw, and revolving with the shaft. The

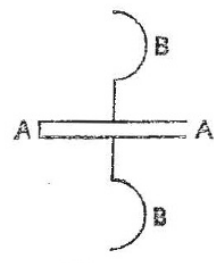

FIG. I.

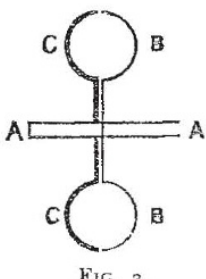

FiG, 2, disc is not flat throughout, its entire zone being shaped into a channel of semi-oval section, which sweeps round the whole circumference concentrically to the axis. To give definiteness to the conception, imagine that, to deal with an engine of 2,000 Ind. horse-power, making 90 revolutions per minute, the diameter of the turbine-disc to the outer border of the channel is five feet.

In Fig. 2, Fir. 1 is repeated, and. what has been called "the casing" is added, being indicated by the letters C C, D D, the former representing the front and the latter the back. The face carries a channel, the counterpart of that carried by the disc, which it also fronts precisely, so that the two semi-oval channels in effect form one complete oval channel, though the two halves are in substance separated by an imaginary plane of division. The back of the casing embraces or includes the disc entirely, but without touching it ; the casing is also provided with a boss, which is an easy fit over that of the disc or turbine, and thus the disc carried by the shaft can revolve within the casing without touching it, while the casing itself is stationary, and one half of the oval channel is running round while the o her half is at rest.

Thus far the two half channels have been regarded as open and unobstructed; they are, however, in fact each closed or cut across by a series of fixed diaphragms, a single one of which is shown in Fig. 3, as in its place in the disc-channel. The diaphragms cut the channel, not perpendicularly, but obliquely, being semicircular in outline, so that when placed obliquely their circular edges fit the oval bottom of the channel, while their diameters span the major axis of the oval Fig. 4 shows one of the diaphragms seen end on or edgeways, as it would appear in an edgeways view of the turbine if this were transparent.

Each half channel has twelve of these diaphragms, and is thus divided into a series of cells, each of which, if viewed at right angles to one of the diaphragms, or what is the same thing, if shown in a section taken parallel to one of them, is semicircular in outline; and if thus viewed in connection with the cell which is for the moment opposite to it in the counterpart half channel, the two together make one complete cell with circular outline.
Thus the whole oval channel may be regarded as a series of obliquely placed circular cells, and as the function of the turbine is to rotate while the casing remains at rest, one half of each cell is moving past the other half in such a manner that the moving half, if viewed from its stationary counterpart, would by reason of the oblique direction of the diaphragms which form the cell sides, appear to be advancing antagonistically towards it ; indeed the motion virtually constitutes such an advance, because the bottom of each moving half cell is continually growing nearer to the bottom of the stationary balf cell which it faces. The effectiveness of the combination to resist rotation will he seen to depend essentially on this quasi-antagonistic virtual approach of the moving to the stationary half cell.

The channel and the whole casing is filled with water, and the turbine is made to rotate as described. When the turbine is thus put in motion, the water contained in each of its half cells is urged outwards by centrifugal force; and in obeying this impulse it forces inwards the water contained in the stationary casing half cells, and thus a continuous current is established, outward in the turbine's half cells, inward in those of the casing.

Now the action of these cells on the water contained in them may be rendered more clear by the following illustration :-Suppose a person in a railway train moving at a certain velocity to hold a racket fixedly in his hand and a ball thrown to him strikes the racket; also that there is provided a series of walls beside the railway inclined at such an angle that the ball leaving the racket and striking one of the walls will rebound to the racket. Suppose, also, for the sake of simplicity, that the ball is perfectly rigid while the walls and racket are perfectly elastic. On striking the racket for the first time the ball will rebound with a velocity equal to double that of the train added to the original velocity of projection. In order to see this clearly we must look at what

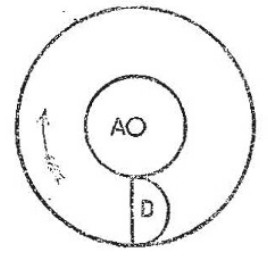

F1G. 3 .

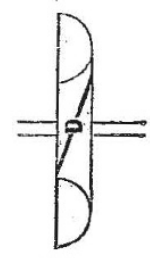

FIG. 4 . takes place in the racket. The ball meets the racket with a velocity equal to that of projection added to that of the train, the strings of the racket stretch to such an extent that their recoil would cause the ball to rebound with the sum of these velocities. At this instant suppose the train stopped, and we should then see the ball projected through the air with the sum of these velocities in consequence solely of the elastic reaction of the racket. But in the experiment we are supposing the train is not stopped but is at this instant capable of impressing on a ball at rest the full velocity of the train; this it does equally well on the ball, which we imagine, for the instant, resting against the strained racket. Thus we see that the ball will be projected through the air with a velocity equal to that of the train in addition to that with which it would have been impressed on it by the racket had the train been stopped at the moment indicated, or, in other words, its velocity of projection will, after one contact with the racket, have had added to it twice the velocity of the train. Each time the ball, rebounding from the walls in succession, meets the racket, an additional double train-velocity will be impressed on it. Another important point in this illus. tration must not be passed over. The action of the ball on the racket tends to retard the train, and that on the walls tends to pusin them forward in the direction of train as well as away from the line of railway.

In an analogous manner the currents originated solely by centrifugal tendency, in being unceasingly reversed in direction and increased in velocity by the opposing cells, produce a resistance to the rotation of the turbine which is measured by the torsion it produces on the casing. This torsion is most conveniently measured by a spring balance attached to the end of a lever made fast to the casing.

The manner in which the currents, when established, produce the dynamometric reaction, can be traced very easily. The explanation already given of the internal form of the cells which the current traverses, shows that the volume of water which constitutes it in each complete cell may be regarded as a circular 
plane or disc of water, rotating in its own plane between the diaphragms, which define the direction of the water disc and which are the boundaries of its thickness.

Having now traced the modus operandi by which the reaction is produced, it is necessary to show that $(\mathrm{x})$ an adequate amount of total reaction can be produced by an instrument of conveniently limited dimensions; and that (2) iti instrument of given dimen. sions is governable as regards its reactions, that is to say, is capable of being made to produce at pleasure a greater or less reaction with a given number of revolutions, so that within

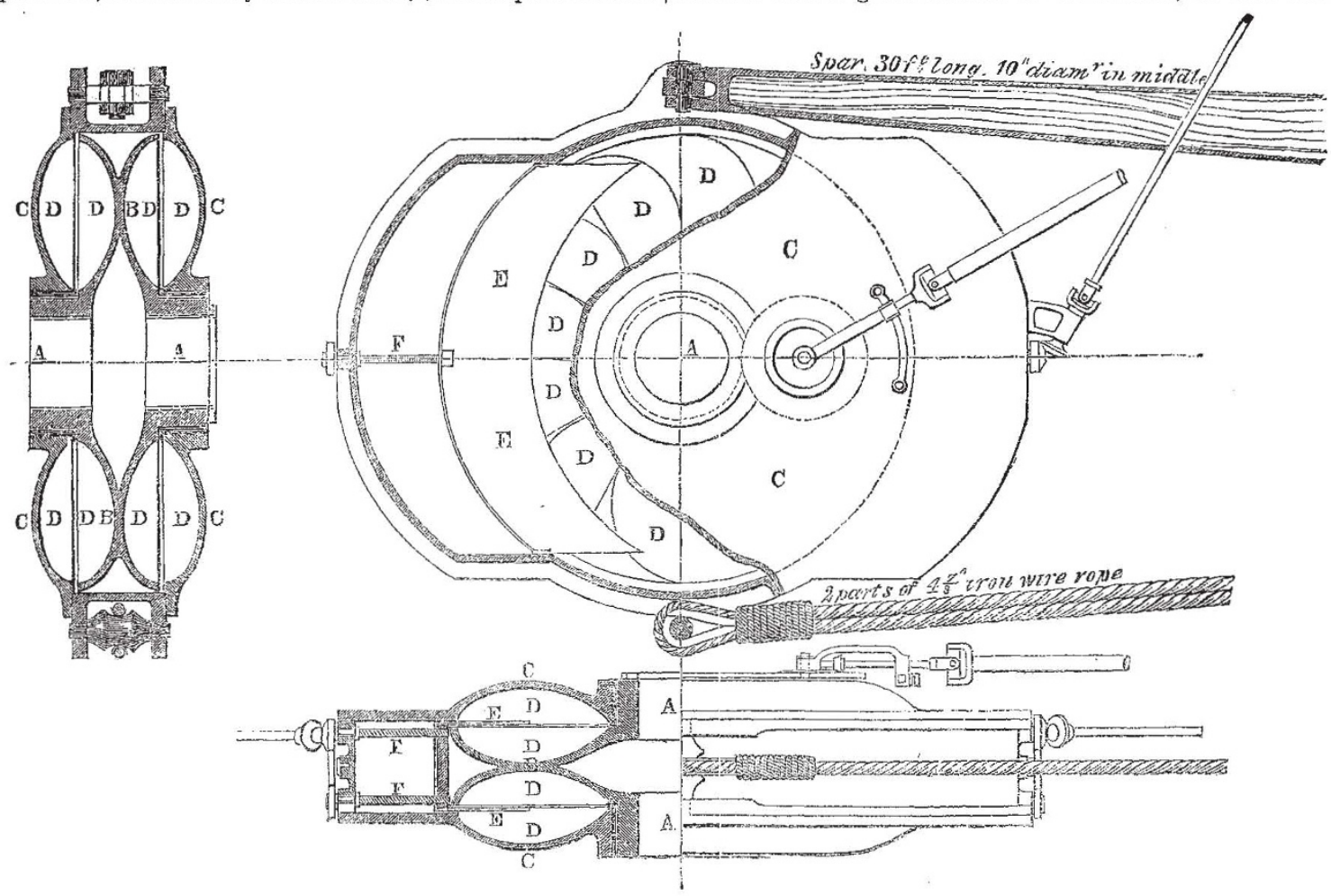

Enlarged view of dynamometer atlached to screw shatt.

reasonable limits the same instrument shall be capable of dealing in the appendix, that, comparing two strictly similar but differwith engines of great or small power, allowing each to make its proper number of revolutions.

As regards condition No. 1 , the theory shows, as will appear ently dimensioned instruments, their respertive "moments of reaction" with the same speed of rotation in each, should be as the fifth powers of their respective dimensions.

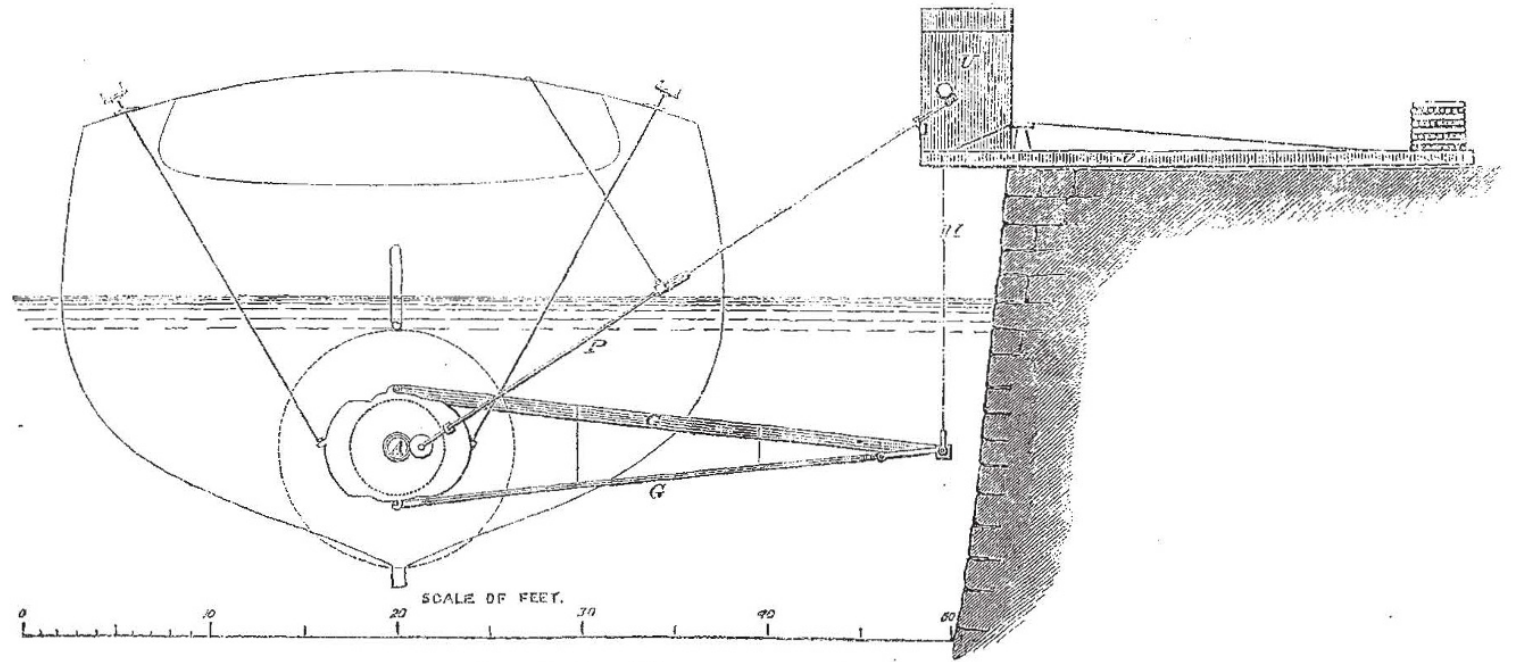

General view of dy namometer attached to screw shaft.

This proposition is fully borne out by experiment. Mr. Froude has had a pair of similar instruments made, in which the turbine diameters are respectively 12 in. and $9^{\cdot} x$ in. Now $\left(\frac{12}{9^{\circ}}\right)^{5}=4$, and accordingly the ratio of the moments of the two instruments at a given speed of turbine rotation should also have been 4 . The ratio was in fact 3.86 ; but the small difference is referable to the circumstance that in the larger of the two instruments the internal surface was rather less smooth and the friction of the water corsequently rather greater than in the other. The data 
thus obtained not only verify the scale of comparison based on the 5 th power of the dimension, but the v also furnish a starting-point by which to quantify the dimensions of the instrument which will be required to deal with any given horse-power delivered with a certain number of revolutions per minute; and it thus appears that to command the measurement of 2,000 horse-power celivered with 90 revolutions per minute (a fairly typical speed

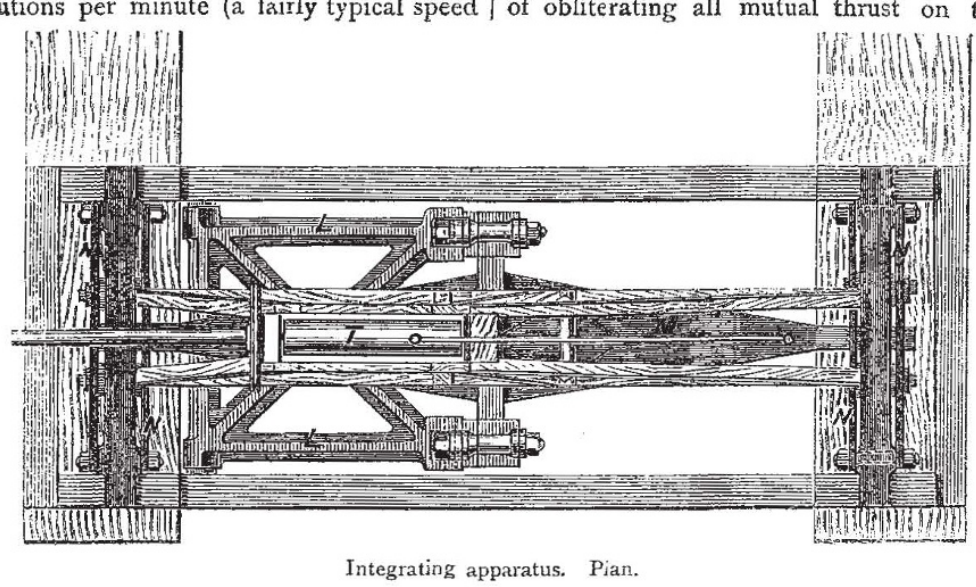

centrifugal forces of the double set of vortices pressing with same, the moment of reaction due to a given speed of rotation equal intensity on the two internal opposite faces of the rigid could be greatly reduced.

casing.

As regards condition No. 2, the theory suggests that, by contracting the internal waterways, that is to say the passages through the cells in the turbine and the casing, and thus intercepting the free vortical rotation, all other things remaining the

The experiments with the models fully bore out this anticipation also, and proved that, by the very simple arrangement sbown in the drawings, the reaction with any given speed of turbine rotation can be reduced with a perfectly graduated progression in any required ratio down to $I-I 4$ th, the object

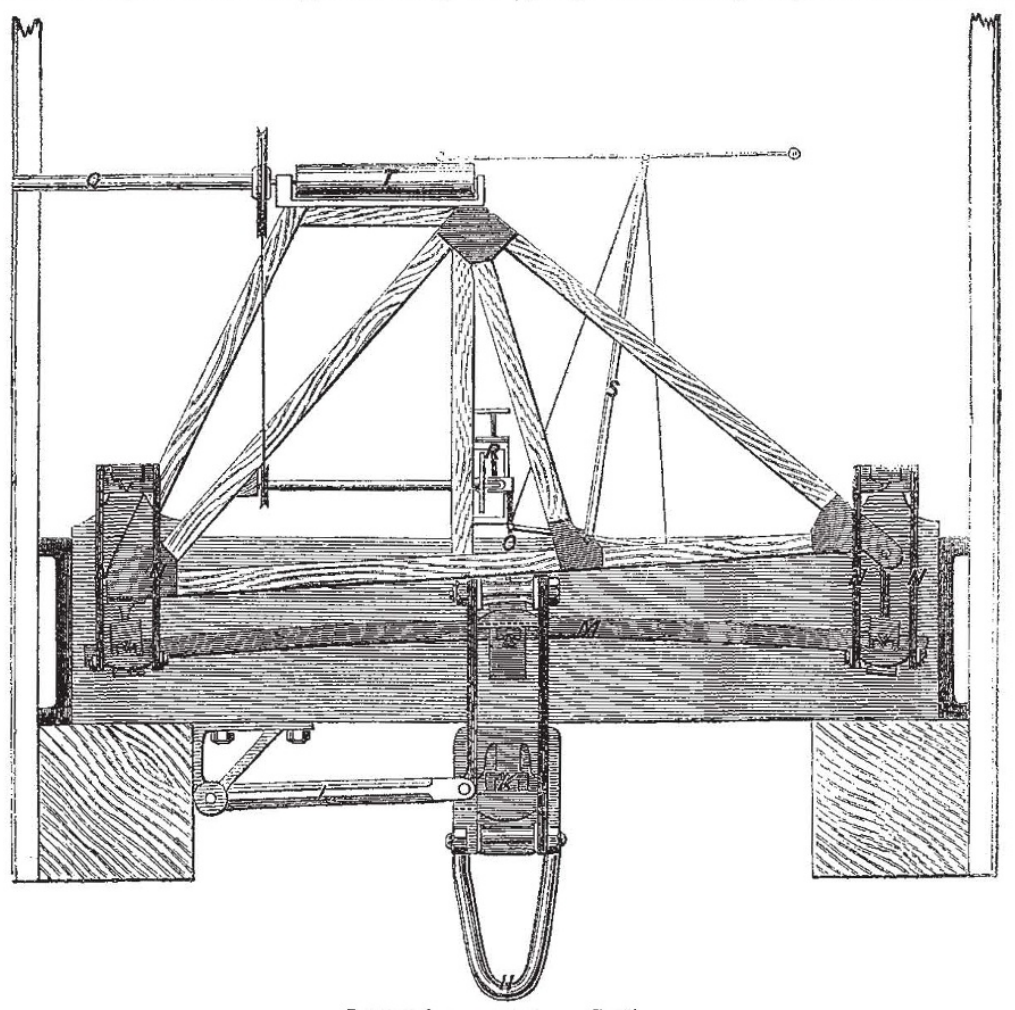

Integraing apparatus. Section.

being effected by advancing, from recesses in the casing abreast | of dealing with an engine of 2,000 horse-power, making ninety ot the two opposite quadrants in each turbine, a lunette-shaped sliding shutter of thin metal, so fitted as to be carried forward (by a screw motion governed from the outside) along the divisional plane between the turbine cells and the casing cells. The intensity of the reaction is thus brought completely and easily under command; and in virtue of it, it follows that the instrument represented in the drawing, which, as already stated, is capable variation is somewhat the same as that which the engine itself 
experiences when propelling the ship under natural conditions, it follows that the same setting of the shutters which suits a given engine when working with its highest speed and power will also approximately suit it when eased down to its lowest.

It remains to be explained in detail how it is proposed to carry out the operation in dealing with any given ship.

The ship, beiore she leaves the dock for the trial of her machinery, will have the instrument mounted as described, in place of her screw. The casing will be provided with proper apertures, capable of being closed at will, to permit the egress of air and the ingress of water as the dock fills. The casing will thus be in a condition to receive the moment of rotation delivered by the screw and communicate it to the recording apparatus.

The arrangement of the dynamometric apparatus presents no difficulty. In this, the downward pull delivered by the lever operates vertically on the midale of a flat horizontal steel spring, which is supported at both ends; and it is proposed so to proportion the spring that its maximum deflection shall be about $1 \frac{1}{2}$ inches. Different springs, however, would be required for engines if of widely different power.

Reference has previously been made to the amount of heat developed by friction in the friction brake, as probably the most formidable of the objections to its employment when the horsepower to be dealt with is as large as that now contemplated. But it must not be supposed that the absorption of the same amount of work in the instrument that has been described will fail to be converted into the same amount of heat here also. The dynamic theory of heat is unquestionable as a theory, and the quantitative relation of work and heat is known with certainty within far narrower limits than deserve even to be mentioned in reference to the present subject. Although, however, the extinction of say 2,000 horse-power will in fact here, as well as in the friction brake, consist in its convercion into so many units of heat, the circumstances of the conversion are entirely different in the two cases, and the difference is such as to obliterate here the inconvenience which was fatally great there. There, the heat was to be dealt with as being constantly developed between surfaces in close contact and inaccessible to water. Here, it will be making its appearance in the body of a mass of water; and though the rapidity of the development will be so great that the whole contents of the casing would be quickly raised to boiling heat if the heat had no escape, yet, in the first place, there is a considerable refrigerating power always at work, since the whole casing is enveloped in cold water, and, moreever, there is no difficulty in creating a constant change of water within the casing sufficient to keep down the mean internal tem. perature to any limit which may be thought proper. For instance, when the instrument is dealing with 2,000 horse-power, the temperature would be kept well below the boiling point if in each minute eight cubic feet of cold water he substituted for the same quantity of the hot contents of the casing, nor would the exactness of the dynamometric action be in the smallest degree impaired by the substitution.

Mr. Froude in his valuable paper, to which we are glad to call attention, thus summarises briefly the advantager which would be derived from the system of submitting marine engines to dynamometric trial. It is certain that a very large but unmeasured amount of power is wasted, in friction and otherwise, between the cylinders and the propeller; and that the amount probably differs, both in respect of difference in type of engine and in respect of goodness of construction and workmanship. The chief difficulties which thus arise are as follows :-

(I) The speed attained by a given ship, driven by a given indicated horse-power, fails to measure discriminatively the merits of the ship.

(2) No means exist of testing which type of engine delivers the largest proportion of the power which it indicates.

(3) No test exists by which to measure concisely the specific constructional merit of this or that engine, or to determine the relative constructional merit of the engines supplied by different firms.

The dynamometric test would remove at once each of these difficulties, by substituting a final and real test for a collateral and to a large extent a delusive one. For to rely exclusively on the test furnished by the indicator is almost equivalent to testing the power of a horse solely by the quantity of food he consumes and digests, or the efficiency of a boiler solely by the quantity of coal per hour it will legitimately consume on its firebars.
Table of Reference Letters used in Diagrams and Drawings.

\section{A. Screw shaft.}

B. Turbine.

C. Casing.
D. Diaphragms.

E. Sliding regulating shutters

F. Screws for moving E, governed by telescopic rods actuating bevel gear controlled from ship's deck

G. Lever for holding casing.

$\mathrm{H}$. Links connecting $\mathrm{G}$ with dynamometric apparatus.

$\mathrm{K}$. Knife-edged gimbal for carrying strain of $\mathrm{H}$ to spring.

$\mathrm{L}$. Framed radius for guiding $\mathrm{K}$ and eliminating oblique strains.

M. Dynamometer spring.

N. Suspension links carrying the ends of $M$

O. Feeler conveying elastic motion of $M$.

P. Telescopic rod taking rotation of screw shaft by bevel gear and commu nicating it to integrating apparatus.

Q. Motion axis of integrating apparatus governed by $\mathrm{O}$.

R. Automatic integrator.

S. Bell crank for magnifying motion of $\mathrm{O}$ and conveying it to paper cylinder:

T. Paper cylinder recording magnified motion of $\mathrm{O}$

The graphic integration of the record given by $\mathbf{Y}$ is comparable with the automatic integration given by $R$.

U. Shed covering integrating apparatus

\section{THE COMMISSION OF THE FRENCH ACA. DEMY AND THE PASTEUR - BASTIAN EXPERIMENTS}

IN further reply to a communication of mine to the Academy of Sciences of Paris on July 10, 1876, and as his latest con. tribution to a controversy which grew out of it, M. Pasteur, at the séance of January 29, 1877, threw down a very definite challenge.

The discussion was raised according to M. Pasteur by my statement, "that a solution of boiled potash caused bacteria to appear in sterile urine at $50^{\circ} \mathrm{C}$., after it had been added to the latter in quantity sufficient for exact neutralisation," and he then said :- "I defy Dr. Bastian to obtain, in the presence of com. petent judges, the result to which I have referred with sterile urine, on the sole condition that the solution of potash which he employs be pure, i.e., made with pure water and pure potash, both free from organic matter. If Dr. Bastian wishes to use a solution of impure potash I freely authorise him to take any in the English or any other Pharmacopoeia, being diluted or concentrated, on the sole condition that that soiution shall be raised beforehand to $110^{\circ}$ for tzventy minutes, or to $130^{\circ}$ for five minutes. . . This is clear enough, it seems to me, and Dr. Bastimn will understand me this time."

At the séance of February I2 my reply was read. The essential part of it was as follows :- "During the last week I have repeated my experiments several times, and with a degree of precaution going much beyond the severity of the convitions prescribed by M. Pasteur. ... I repeated them at first with liquor potassa which had been previously raised to $110^{\circ} \mathrm{C}$. for sixty minutes, and afterwards with liquor potassa which had been raised, in the same manner, to $110^{\circ} \mathrm{C}$. for trventy hours. The results have been altogether similar to those produced upon sterile urine by liquor potassee which has been raised only to $100^{\circ}$, when added in suitable quantity; that is to say, in twenty. four to forty-eight hours the urine was in fult formentation and swarmed with bacteria."

After the reading of this reply, M. Pasteur asked the Academy to appoint a Commission to report upon the subject in dispute, and at the next meeting of the Academy (February 19) it was announced that "MM. Dumas, Milne Edwards, Boussingault sont designés pour constituer la Commission qui sera appelée à exprimer une opinion sur le fait qui est en discussion entre M. le Dr. Bastian et M. Pasteur."

The following correspondence then ensued :-

\section{0, Queen Anne Street, W., February 27, 1877}

DeAr Sir,-I was pleased to learn, from the Comptes Rerdus, yesterday, that the Academy had appointed you together with MM. Milne Edwards and Boussingault to act as a Commission to "express an opinion on the fact" now under discussion between M. Pasteur and myself.

I can scarcely suppose that the Commission would deem it expedient to express an opinion on this subject without having an opportunity of seeing both M. Pasteur and myself perform our respective experiments

I write, therefore, to inform you that if a convenient time can be arranged, I shall be very happy to come to Paris for three days 